\title{
Study the adsorption of sulfates by high cross-linked polystyrene divinylbenzene anion-exchange resin
}

\author{
Mahmoud Fathy • Th. Abdel Moghny • \\ Ahmed E. Awadallah • Abdel-Hameed A-A El-Bellihi
}

Received: 12 March 2014/ Accepted: 16 October 2014/Published online: 28 November 2014

(C) The Author(s) 2014. This article is published with open access at Springerlink.com

\begin{abstract}
In response to rising concerns about the effect of sulfate on water quality, human health, and agriculture, many jurisdictions around the world are imposing tighter regulations for sulfate discharge. This is driving the need for environmental compliance in industries like mining, metal processing, pulp and paper, sewage treatment, and chemical manufacturing. The sulfate removal from synthetic water by high cross-linked polystyrene divinylbenzene resin was studied at batch experiments in this study. The effect of $\mathrm{pH}$, contact time, sulfates concentration, and adsorbent dose on the sulfate sequestration was investigated. The optimum conditions were studied on Saline water as a case study. The results showed that with increasing of the absorbent amount; contact time, and $\mathrm{pH}$ improve the efficiency of sulfate removal. The maximum sulfates uptake was obtained in $\mathrm{pH}$ and contact time 3.0 and $120 \mathrm{~min}$, respectively. Also, with increasing initial concentration of sulfates in water, the efficiency of sulfate removal decreased. The obtained results in this study were matched with Freundlich isotherm and pseudo-secondorder kinetic. The maximum adsorption capacity $(\mathrm{Qm})$ and constant rate were found $0.318(\mathrm{mg} / \mathrm{g})$ and $0.21(\mathrm{mg} /$
\end{abstract}

M. Fathy $(\bowtie) \cdot$ Th. A. Moghny

Applications Department, Egyptian Petroleum Research Institute

(EPRI), 1 Ahmed El-Zomer, Nasr City, Box. No. 11727,

Cairo, Egypt

e-mail: Dr.Abo_fathy@yahoo.com; fathy8753@yahoo.com

\section{A. E. Awadallah}

Development of processes Department, Egyptian Petroleum

Research Institute, 1 Ahmed El-Zomer, Nasr City,

Box. No. 11727, Cairo, Egypt

A.-H. A.-A. El-Bellihi

Faculty of Science Banha University, Fred Nada Street,

Banha, Cairo, Egypt g.min), respectively. This study also showed that in the optimum conditions, the sulfate removal efficiency from Saline water by $0.1 \mathrm{mg} / \mathrm{L}$ sulfates was $65.64 \%$. Eventually, high cross-linked polystyrene divinylbenzene resin is recommended as a suitable and low cost absorbent to sulfate removal from aqueous solutions.

Keywords Adsorption - Saline water - Adsorption capacity · Water · Hard

\section{Introduction}

Sulfates are widely popular for this application because of its ability to kill bacteria and other disease-causing organisms at relatively low concentrations. The sulfates bind and destroy the outer surface of bacteria and viruses thereby preventing waterborne diseases. The sulfates that are not used are called free residual sulfates. There are many health concerns regarding residual sulfates in water. This is mainly because sulfates are not naturally needed by the body, and as a halogen, it tends to inactivate enzymes (Okuo et al. 2008). Chlorinated water contains chemical compounds called tri halothanes which are carcinogens. Bathing with chlorinated water could have the same effect as drinking because of dermal absorption of sulfates (Nedalee and Abdullah 2009). Other concerns are aesthetic such as sulfate taste and odor. These concerns inform the need for an effective means of water dechlorination after disinfection at low cost. In Europe, the most common means of destroying microorganisms in water system is the use of ozone treatment. In Nigeria, sulfates are extensively used in water treatment because it is cheaper than ozone. High cross-linked polystyrene divinylbenzene resin are good at removing sulfate residual from water but the actual 
rates of sulfate removal by high cross-linked polystyrene divinylbenzene resin obtained from different local raw materials need to be determined. Fast adsorption rate and high adsorption capacity are important and must be considered in the selection of an activated carbon for a given purpose. The performance of high cross-linked polystyrene divinylbenzene resin is indicated by its adsorptive characteristics, which is derived from the specific surface area, pore size, and pore volume of the high cross-linked polystyrene divinylbenzene resin. In this study, adsorption isotherms and sulfate removal kinetics from water using high cross-linked polystyrene divinylbenzene resin from selected local raw materials were considered (Kleiner and Eggert 2001).

\section{Experimental}

Materials and methods

\section{Instruments and materials}

All the chemicals used throughout this study were of analytical grade. All the adsorption experiments were carried out at $25^{\circ} \mathrm{C}$ an agitation speed $100 \mathrm{rpm}$. A stock solution of sulfates was obtained by dissolving $\mathrm{Na}_{2} \mathrm{SO}_{4}$ salt $(2.21 \mathrm{~g})$ in distillated water $(1,000 \mathrm{~mL})$. $\mathrm{HCl}$ and $\mathrm{NaOH} 0.1 \mathrm{~N}$ were used to adjust samples $\mathrm{pH}$. Sulfate concentration was measured by Hanna C 200 model.

\section{Synthesis of polystyrene divinylbenzene (PS-DVB) copolymer beads}

The PS-DVB copolymer beads were prepared by suspension polymerization technique. The initiator (benzoyl peroxide) was dissolved in the monomers (styrene and divinylbenzene) and the diluents. Such mixture was added to the suspension solution formed by dissolving $\mathrm{HB}$ in deionized water. Then all were poured in $1 \mathrm{~L}$ four-neck flask fitted with a mechanical stirrer, nitrogen inlet, condenser, thermometer, and pressure indicators, and the reaction mixture was heated to $75^{\circ} \mathrm{C}$ and was allowed to proceed at this temperature for $6 \mathrm{~h}$ and at $90{ }^{\circ} \mathrm{C}$ for another $18 \mathrm{~h}$ under nitrogen atmosphere with constant stirring at $300 \mathrm{rpm}$. After that, the copolymer beads were filtered and washed with dilute $\mathrm{HCl}$ solution and enough quantity of hot water and extracted with acetone, then dried at $150{ }^{\circ} \mathrm{C}$ and sieved. To measure the toluene regain, the copolymer beads were swollen to equilibrium in toluene for at least 1-week. Then, they were washed first with acetone and finally with pure methanol (Ghaderi et al. 2006; Matheel Al-Sabti et al. 2007).

\section{Anion exchange copolymer resins}

A $2.0176 \mathrm{~g}$ of resins, $2,5 \mathrm{ml}$ of chloromethyl methyl ether, $1.1530 \mathrm{~g}$ of $\mathrm{ZnCl}_{2}$, and $10 \mathrm{ml}$ of nitrobenzene were added to a $50 \mathrm{ml}$ flask equipped with refluxing condenser and anhydrous $\mathrm{CaCl}_{2}$ tube. After stirring at room temperature for 5-10 min, the chloromethylation reaction was carried out at $45^{\circ} \mathrm{C}$ for $4 \mathrm{~h}$. After that, $0.5770 \mathrm{~g}$ of $\mathrm{ZnCl}_{2}$ was added to the system, the polymerization was carried out at $80{ }^{\circ} \mathrm{C}$ for $12 \mathrm{~h}$. The resulting polymer washed with hot deionized water, and extracted with acetone in a Soxhlet apparatus. The product was dried under vacuum to give $2.3907 \mathrm{~g}$ of resin (Cristiane Martins et al. 2003). Then a $250 \mathrm{~mL}$ round-bottom flask fitted with magnetic stirrer was charged with $5 \mathrm{~g}$ of polymer beads, $150 \mathrm{ml}$ of acetonitrile, and $30 \mathrm{ml}$ of tri ethylamine, then the mixture was purged with nitrogen, deaerated under vacuum and the entire setup was placed in an oil bath over a magnetic stirrer and the mixture was refluxed at $70 \mathrm{C}^{\circ}$ for 3 days with a continuous pumping of nitrogen into the reaction flask. The quaternized beads were filtered and successively washed with acetonitrile and methanol followed by drying under vacuum at $60{ }^{\circ} \mathrm{C}$ (Balakrishnan and Murugan 2003).

\section{Effect of $\mathrm{pH}$ value on sulfate adsorption}

The effect of $\mathrm{pH}$ on sulfate ions adsorption was carried out using initial sulfate ion concentration $100 \mathrm{mg} / \mathrm{L}$ onto 0.1 $\mathrm{g} / \mathrm{L}$ of resins at different $\mathrm{pH}$ values (1-9). The solution was agitated for $120 \mathrm{~min}$ and the residual sulfate ion in solutions was determined, also the distribution of chloride ion depends upon $\mathrm{pH}$ of the solution were studied (Malakootian et al. 2011).

\section{Effect of sorbent dose}

The effects of changing initial resin dosage in the sorption medium on removal of sulfate ions in terms of adsorption capacity was examined at different values including 0.10 , $0.050,0.1$, and $0.2,0.3,0.35 \mathrm{~g}$ resin/L and equilibrated for $24 \mathrm{~h}$, while other operational parameters such as temperature and initial sulfate ion concentration of solutions were kept constant $\left(\mathrm{T}=30^{\circ} \mathrm{C}, \mathrm{C}_{0}=100 \mathrm{mg} \mathrm{M} / \mathrm{L}, \mathrm{pH}=\right.$ natural) (Gurnule and Dhote 2012).

\section{Effect of initial sulfate concentration}

$1,000 \mathrm{mg} / \mathrm{L}$ stock solution of sulfate ions was diluted to obtain standard solutions containing $10-100 \mathrm{mg} / \mathrm{L}$ of chloride ion. A $100 \mathrm{~mL}$ of sulfate ion solutions of a desired concentration was adjusted to a desired $\mathrm{pH}$, then poured in $300 \mathrm{~mL}$ reaction bottles and known amounts of ion exchange resins were added. The solution $\mathrm{pH}$ was adjusted 
using buffer solutions. The solutions were agitated at $150 \mathrm{rpm}$ for a predetermined period at $30{ }^{\circ} \mathrm{C}$ in a shaking incubator (JEIO TECH SI-900R). The resins were separated and the filtrate was analyzed by ICP for chloride ion content (Gurnule and Dhote 2012).

\section{Results and discussion}

Effect of $\mathrm{pH}$ value on sulfate uptake

The $\mathrm{pH}$ of the ion exchange system determines the adsorption capacity due to its influence on the surface properties of the different ionic forms of the sulfate solutions. Changes of the adsorption capacity of sulfate onto prepared resins with $\mathrm{pH}$ are shown in Fig. 1. It was observed that the maximum removal percentage $(65 \%)$ occurred at $\mathrm{pH}$ 2.5. Maximum adsorption at acidic $\mathrm{pH}$ indicates that the low $\mathrm{pH}$ leads to an increase in $\mathrm{H}^{+}$ions on the resin surface which results in significantly strong electrostatic attraction between positively charged anionic PS-DVB resin surface and sulfate ions. The removal percentage of sulfate adsorption gradually decreased to $11.8 \%$ at $\mathrm{pH}$ 9. Adsorption of sulfate onto ion exchange resins were not significant at $\mathrm{pH}$ values greater than 6.0 due to anions competition to be exchanged on the surface of the prepared ion exchange resins of which $\mathrm{OH}^{-}$predominates. The $\mathrm{pH}$ of exchanged ions is a very important character that determines the $\mathrm{pH}$ at which the ion exchange resin surface has net electrical neutrality. At this value, the acidic or basic functional groups no longer contribute to the $\mathrm{pH}$ of the solution (ApteSagar et al. 2011).

\section{Effect of initial sulfates concentration}

The amount of sulfate anions adsorbed for different initial concentrations onto anionic PS-DVB resins is shown in Fig. 2. The results show that the adsorption process is

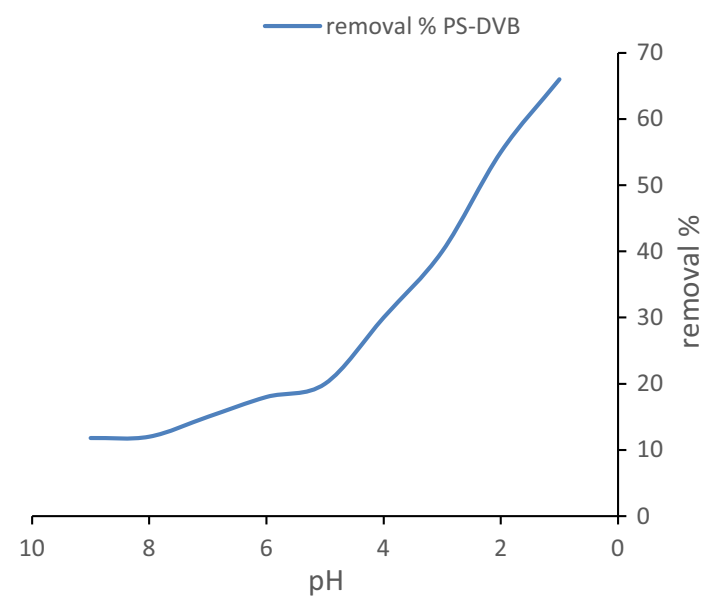

Fig. 1 Effect of $\mathrm{pH}$ value on sulfate uptake clearly time dependent. The amount of sulfate adsorbed $(\mathrm{mg} / \mathrm{g})$, increased with increase sulfate concentration and remained nearly constant after equilibrium time. It was shown that the adsorption at different initial concentration was rapid in the initial stages and gradually decreased with the progress of adsorption until the equilibrium reached $120 \mathrm{~min}$. At low concentrations, the ratio of available surface to the initial sulfate concentration is large, so the removal becomes independent on initial concentrations. However, in the case of the high concentrations, this ratio is low, and the exchange rate then depends upon the initial concentration. In addition, the curves are continuous leading to saturation, suggesting the monolayer coverage of sulfate on the surface of the adsorbent (Koumaiti et al. 2011).After a balance time of $120 \mathrm{~min}$, the adsorption capacity records an increase from 11 to $83.2 \mathrm{mg} / \mathrm{g}$, for concentrations from 25 to $100 \mathrm{mg} / \mathrm{L}$ in PS-DVB resin. This may be due to the fact that at a chosen adsorbent dose, the number of active adsorption sites remains unchanged while with higher adsorbate concentrations, the adsorbate ions to be accommodated increase. At the higher initial concentrations, the higher corresponding cumulative removal $(\mathrm{mg} / \mathrm{g})$ is dominated. The small amount of exchange sulfate ions evidence that the presence of carbon nanotubes create specialized resin rate that is satisfactory for chlorine ion more than sulfate ions and this reduces the competition between them which is clear in the resin containing MWCNTs.

\section{Effect of sorbent dose}

To examine the effect of the resin dosage on the removal efficiency sulfate, adsorption experiments were set up with various amounts of anionic PS-DVB resin (0.05-0.35 $\mathrm{g} / 100 \mathrm{~mL}$ ) at initial sulfate concentration of $100 \mathrm{mg} / 100 \mathrm{~mL}$ and at $\mathrm{pH}=3.5$. The effect of resin dosages on the amount of adsorbed sulfate has been shown in Fig. 3. It was shown

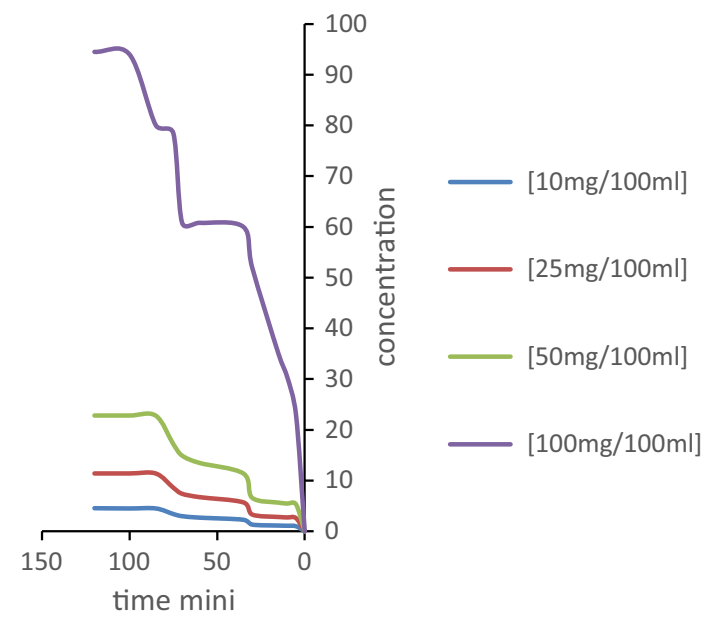

Fig. 2 Effect of initial sulfate concentration

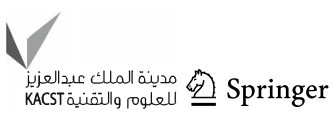




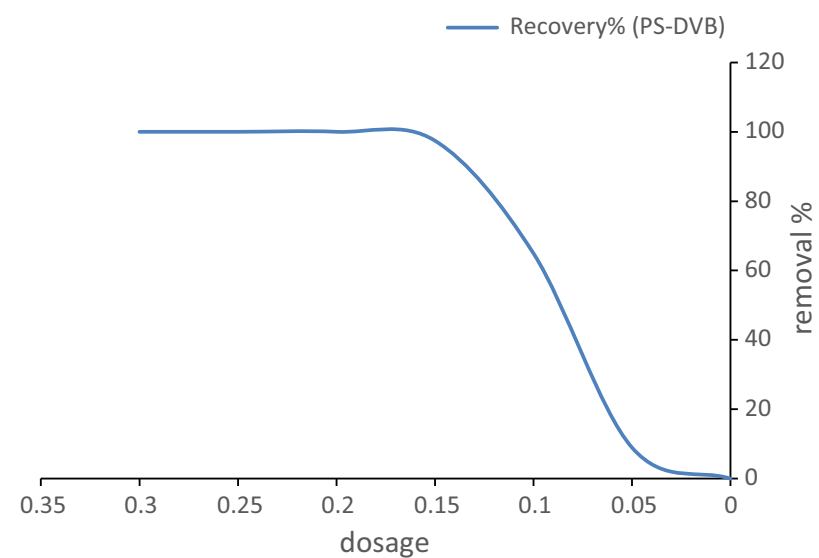

Fig. 3 Effect of sorbent dose

Table 1 Summary of isotherm parameters for the adsorption of sulfate ions on anionic exchange resins

\begin{tabular}{|c|c|c|c|c|c|c|c|c|}
\hline \multirow[t]{2}{*}{ Resins } & \multicolumn{5}{|c|}{ Freundlich } & \multicolumn{3}{|c|}{ Langmuir } \\
\hline & $1 / n$ & $N$ & $K$ & $R^{2}$ & $1 / X_{\mathrm{m}}$ & $X_{\mathrm{m}}$ & $R^{2}$ & $K_{\mathrm{L}}$ \\
\hline PS-DVB & 3.17 & 0.3148 & 49.488 & 0.9838 & 0.1498 & 1.35 & 0.7169 & 1 \\
\hline
\end{tabular}

that the quantity of sulfate adsorbed increased in significant values in the pondered range examined. In addition, anionic PS-DVB, the recovery $\%$ increased by $100 \%$ from $100 \mathrm{mg} / 100 \mathrm{~mL}$ resin doses. Beyond an adsorbent dose of $250 \mathrm{mg} / 100 \mathrm{~mL}$, the recovery \% becomes constant. This is probably because the resistance to mass transfer of sulfate from bulk liquid to the surface of the adsorbent and the saturation of active sites, which becomes important at high adsorbent loading in the system in which the experiment was conducted. It might have happened that the higher dose causes particle aggregates and interference or repulsive forces between binding sites, therefore, decreases the interaction of sulfate ions with the sorbent and reduces the total surface area of the adsorbent (Koumaiti et al. 2011).

\section{Isotherm data analysis}

In this study, Freundlich, Langmuir isotherms were studied. The Table 1 gives the isotherm equation as well as constants. According to the results, the Freundlich isotherm was best fitted to represent the equilibrium adsorption data than other isotherms (Figs. 4, 5). RL (separation factor) is the important factor in Langmuir isotherm that is the dimensionless constant (Koumaiti et al. 2011).

Kinetic studies

Sulfate removal from aqueous solution by pumice may be presented by first-order, second-order, and intraparticle

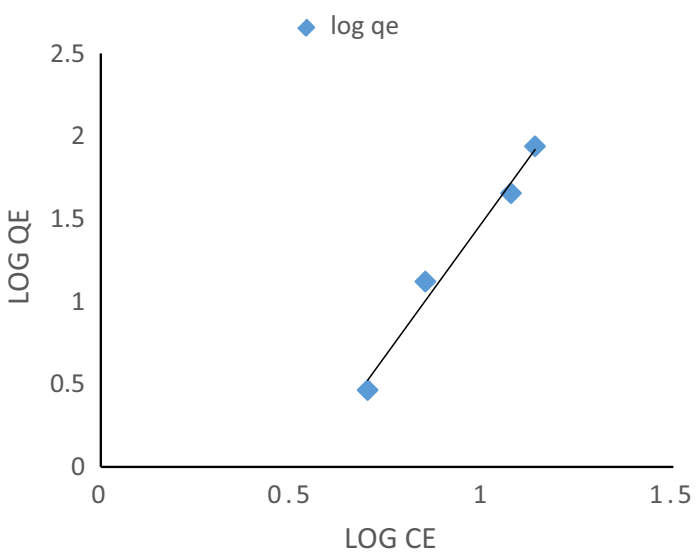

Fig. 4 Langmuir isotherm data analysis of sulfate removals

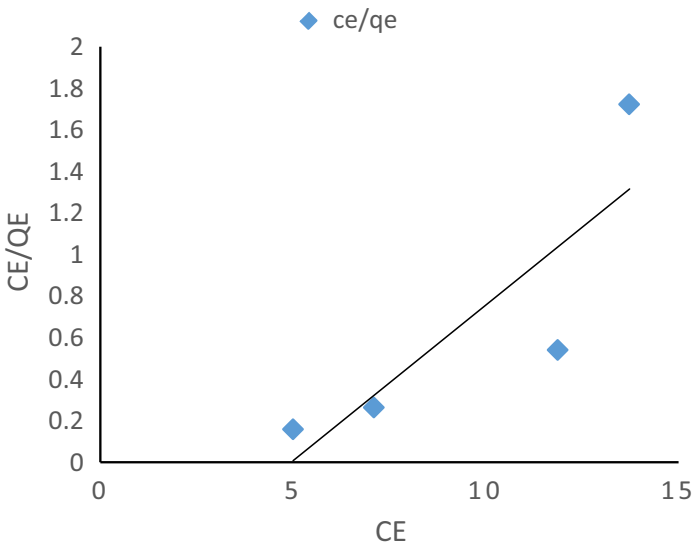

Fig. 5 Freundlich isotherm data analysis of sulfate removals

diffusion kinetic models. Table 2 presents the kinetic equation and constant value for sulfate adsorption on pumice. Sulfates-pumice interaction concurred showed good fit with pseudo-second-order rate equation $\left(R^{2}=0.99\right)$. Figure 5 is shown pseudo-second-order kinetic model (Koumaiti et al. 2011).

\section{Conclusions}

Removal of $\mathrm{SO}_{4}{ }^{2-}$ from aqueous solution onto anionic PSDVB resin was carried out using PS-DVB resins. Results indicate that initial sulfate concentration, $\mathrm{pH}$, and adsorbent dosage impacted sulfate specie removal: the $\mathrm{SO}_{4}{ }^{2-}$ uptake increased with the increase of initial sulfate concentration and decreased with increasing $\mathrm{pH}$ values. It is also seen that a further increase in adsorbent dose (greater than $0.1 \mathrm{mg} / \mathrm{L}$ ) affects the uptake of sulfate adsorption greatly. The equilibrium state was reached within $120 \mathrm{~min}$ of exposure time. The results showed that the adsorption of sulfate onto anionic PS-DVB resin followed pseudo-second-order rate kinetic predicting a chemisorption process. 
Table 2 Kinetic studies of sulfate ion sorption on anionic PS-DVB resin

\begin{tabular}{|c|c|c|c|c|c|}
\hline \multirow[t]{2}{*}{ Kinetic model } & \multirow[t]{2}{*}{ Nonmetal ions } & \multirow[t]{2}{*}{ Metal concentrations } & \multicolumn{3}{|c|}{ Kinetic parameter } \\
\hline & & & $R^{2}$ & $\mathrm{~K}_{\mathrm{L}}$, ads $\mathrm{orKd}$ & $\mathrm{q}_{\mathrm{e}}$ \\
\hline \multirow[t]{4}{*}{ Pseudo-first-order model } & \multirow[t]{4}{*}{$\mathrm{SO}_{4}^{-2}$} & 10 & 0.6375 & 0.0065 & 0.9375 \\
\hline & & 25 & 0.6573 & 0.0071 & 1.2652 \\
\hline & & 50 & 0.9122 & 0.002 & 1.5068 \\
\hline & & 100 & 0.8487 & 0.001 & 1.7655 \\
\hline \multirow[t]{4}{*}{ Second-order model } & \multirow[t]{4}{*}{$\mathrm{SO}_{4}^{-2}$} & 10 & 0.8272 & 0.0002 & 0.1191 \\
\hline & & 25 & 0.7255 & 0.0013 & 0.02 \\
\hline & & 50 & 0.9189 & 0.0005 & 0.0156 \\
\hline & & 100 & 0.9562 & $5 \times 10^{-5}$ & 0.0225 \\
\hline \multirow[t]{4}{*}{ Pseudo-second-order model } & \multirow[t]{4}{*}{$\mathrm{SO}_{4}^{-2}$} & 10 & 0.9984 & 0.3288 & 1.4005 \\
\hline & & 25 & 0.998 & 0.0729 & 0.539 \\
\hline & & 50 & 0.9933 & 0.021 & 0.2331 \\
\hline & & 100 & 0.9989 & 0.0108 & 0.0924 \\
\hline \multirow[t]{4}{*}{ Intraparticle diffusion model } & \multirow[t]{4}{*}{$\mathrm{SO}_{4}^{-2}$} & 10 & 0.6222 & 0.1468 & 1.6015 \\
\hline & & 25 & 0.8012 & 0.7623 & 5.7203 \\
\hline & & 50 & 0.9162 & 2.8452 & 15.841 \\
\hline & & 100 & 0.8832 & 5.3445 & 35.31 \\
\hline
\end{tabular}

The results of present investigation show that the relatively low cost and high capabilities of the raw date palm seeds make them potentially attractive adsorbents for the removal of sulfate from aqueous solution. Further experiments need to be conducted to test the dynamic sorption of $\mathrm{SO}_{4}{ }^{2-}$ onto anionic PS-DVB resin in patch process.

Open Access This article is distributed under the terms of the Creative Commons Attribution License which permits any use, distribution, and reproduction in any medium, provided the original author(s) and the source are credited.

\section{References}

ApteSagar S, ApteShruti S, Kore VS, Kore SV (2011) Universal J Environ Res Technol 1(4):416-422
Balakrishnan T, Murugan E (2003) J. Macromolecular Sci Part A A40(5) 525-546

Cristiane Martins R, Ruggeri G, Marco De Paoli A (2003) J Braz Chem Soc 14(5) 797-802

Ghaderi A, Abbasian M, Rahmani S, Namazi H, Baharvand H, Akbar A (2006) Entezami. Iranian Polymer J 15(6):497-504

Gurnule WB, Dhote SS (2012) Scholars Research Library. Der Pharma Chemica 4(2):791-799

Kleiner A, Eggert S (2001) Phys. Rev. B 64(11):113402-113404

Koumaiti S, Riahi K, Ounaies F, Ben B (2011) Thayer; J. Environ Sci Eng 5:1570-1580

Malakootian M, Moosazadeh N, Yousefi A, Fatehizadeh M (2011) African J. of Environ. Sci Techng 5(4): 299-306

Matheel Al-Sabti D, Jawad Jawad K, Wisam Jacob F (2007) Eng Technol 25: 9

Nedalee R, Abdullah S (2009). Article base. Aeticlebase.com

Okuo JM, Akapaja EO, Eguono WO (2008) J. Chem. Soc. Nig. 33(1):56-64 